\title{
ANALISA DAN DESAIN SISTEM INFORMASI PENJUALAN BERBASIS WEB DENGAN BUSINESS MODEL CANVAS (BMC) PADA IRFANA BATIK TENUN
}

\author{
Rendy Abdullah Malik ${ }^{1}$, Dian Anubhakti ${ }^{2}$, Bima Cahya Putra ${ }^{3}$ \\ ${ }^{1}$ Fakultas Teknologi Informasi, Sistem Informasi, Universitas Budi Luhur, Jakarta, Indonesia \\ Email: ${ }^{1}$ 1612510477@student.budiluhur.ac.id, ${ }^{2}$ dian.anubhakti@ budiluhur.ac.id, ${ }^{3}$ bima.cahyaputra@ budiluhur.ac.id
}

\begin{abstract}
Abstrak-Kemajuan Teknologi Informasi saat ini telah mempermudah manusia untuk memenuhi kebutuhannya, teknologi telah membantu manusia dalam berbagai hal tidak terkecuali dalam hal perdagangan. Penggunaan internet saat ini bukan hanya dimanfaatkan untuk sekedar mencari informasi, menggunakan sosial media namun dimanfaatkan juga untuk melakukan bisnis. ECommerce merupakan pemasaran produk dengan memanfaatkan teknologi informasi khususnya komputer, handphone, laptop dan internet. Irfana Batik Tenun merupakan bisnis yang melakukan pejualan batik. Dalam melakukan aktivitasnya masih memiliki beberapa kendala diantaranya lokasi yang saat ini hanya ada satu membuat pelanggan yang biasanya datang ke lokasi sekarang banyak yang beralih untuk belanja secara online, promosi yang terbatas membuat pelanggan untuk beralih ke penjual yang mempromosikan produknya secara online. Untuk menyelesaikan masalah yang terkait dengan penjualan dan pemasaran produk pada Irfana Batik Tenun maka dibuatlah rancangan sistem informasi berbasis web, sehingga promosi dan penjualan dapat dilakukan secara online dan meluaskan promosi agar pelanggan dapat memiliki produk yang dipasarkan oleh Irfana Batik Tenun. Dengan adanya pemasaran dan promosi secara online diharapkan Irfana Batik Tenun mendapatkan pelanggan baru serta meningkatkan volume penjualan.
\end{abstract}

Kata Kunci: E-Commerce, Teknologi Informasi, Sistem Informasi, Berbasis web

\begin{abstract}
Advances in Information Technology today have made it easier for humans to fulfill their needs, technology has helped humans in various ways, including trade. The use of the internet today is not only used to find information, use social media but is also used to do business. E-Commerce is product marketing by utilizing information technology, especially computers, cellphones, laptops and the internet. Irfana Batik Weaving is a business that sells batik. In carrying out its activities, it still has several obstacles, including the location that currently there is only one, making many customers who usually come to the location now switch to shopping online, limited promotions make customers switch to sellers who promote their products online. To solve problems related to product sales and marketing at Irfana Batik Weaving, a web-based information system design was made, so that promotions and sales can be done online and promotions are made so that customers can have products marketed by Irfana Batik Weaving. With online marketing and promotion, it is hoped that Irfana Batik Tenun will get new customers and increase sales volume.
\end{abstract}

Keyword: E-Commerce, Information Technology, Information Systems, Web-based

\section{PENDAHULUAN}

Irfana Batik Tenun merupakan unit bisnis yang menjalankan bisnisnya dibidang penjualan, khusunya pakaian batik dan tenun. Peminat pakaian batik dan tenun saat ini semakin meningkat khususnya dikalangan remaja dan dewasa. Irfana Batik Tenun merupakan sebuah unit bisnis yang menjual produk berupa kemeja batik untuk kalangan remaja maupun dewasa dengan harga yang bersahabat. Irfana Batik Tenun terletak di kawasan Jakarta Selatan tepatnya dikawasan mayestik. Berdasarkan meningkatkan permintaan untuk kemeja batik tenun, maka ini merupakan sebuah peluang bagi Irfana Batik Tenun untuk memasarkan dan melakukan promosi dengan memanfaatkan teknologi informasi khususnya dengan menggunakan internet. Sistem merupakan prosedur, aturan, mesin dan orang yang bersinergi dalam mencapai tujuan[1], sementara informasi merupakan proses pengolahan data menjadi sesuatu yang lebih berguna [2]. Dengan media online, proses promosi dan penjualan dapat dilakukan dengan efektif dan efisien, kehadiran e-commerce yang merupakan proses jual beli dengan menggunakan dunia maya[3].

Rancangan e-commerce untuk Irfana Batik Tenun merupakan pengembangan sistem penjualan untuk memenuhi kebutuhan perkembangan penjualan dan promosi saat ini, dengan menurunnya penjualan Irfana Batik Tenun saat ini maka perlu sebuah terobosan yaitu melakukan penjualan dengan memanfaatkan media online atau ecommerce untuk membantu memasarkan produk dan meluaskan promosi pada Irfana Batik Tenun. Masalah utama yaitu produk lama yang dimiliki oleh Irfana Batik tenun sulit untuk dipasarkan, kurang luasnya lingkup penjualan karena hanya berjualan disekitar lingkungan toko saja, belum adanya promosi secara online, sehingga menyebabkan tidak bertambahnya calon pelanggan, belum tersedianya sistem retur, sehingga pelanggan tidak bisa mengembalikan barang. Dengan minimnya informasi produk,maka tidak diketahui produk yang terjual dan tidak ditulisnya tanggal dari hasil penjualan menyebabkan rekapitulasi menjadi kacau. Dengan berbagai masalah yang ada pada Irfana Batik 
Tenun maka dalam penelitian ini akan disediakan analisa dan rancangan aplikasi berbasis web yang akan membantu dalam mengatasi masalah yang ada.

Kemudahan dalam penyajian informasi batik yang dipasarkan, update stok batik, informasi pengiriman kepada pelanggan dan informasi yang dapat diakses dari mana saja dan kapan saja meruakan sebuah nilai tambah yang bermanfaat bagi Irfana Batik Tenun. Dengan menggunakan aplikasi berbasis web, promosi produk yang kurang laris dapat ditempatkan di halaman utama, sehingga informasi dan promosi produk yang kurang laris dapat diketahui pelanggan.

\section{METODE PENELITIAN}

\subsection{Metode Pengumpulan Data}

Dalam mendapatkan data yang berguna dalam penelitian ini dilakukan dengan melakukan observasi dan wawancara terkait masalah yang terjadi pada Irfana Batik Tenun, kemudian mendeskripsikan solusi untuk mengatasasi permasalahan yang disesuaikan dengan kebutuhan Irfana Batik Tenun. Langkah pertama mempelajari proses pemesanan, produk yang pada Irfana Batik Tenun. Langkah kedua dilakukan dengan wawancara pada pemilik dan staff Irfana Batik Tenun, wawancara dilakukan karena peneliti ingin mengetahui hal yang mendalam dari responden[4]. Langkah ketiga melakukan analisa dokumen berjalan di Irfana Batik Tenun, dimana dokumen akan dianalisa untuk sistem yang akan dibuat.

\subsection{Metode Pengembangan Sistem}

Dalam penelitian ini metode pengembangan sistem menggunakan waterfall, disebut dengan waterfall karena tahap demi tahap yang dilalui harus menunggu selesainya tahap sebelumnya dan berjalan berurutan[5]. Metode pengembangaan sistem pada Irfana Batik Tenun dapat dilihat pada gambar 1 berikut ini:

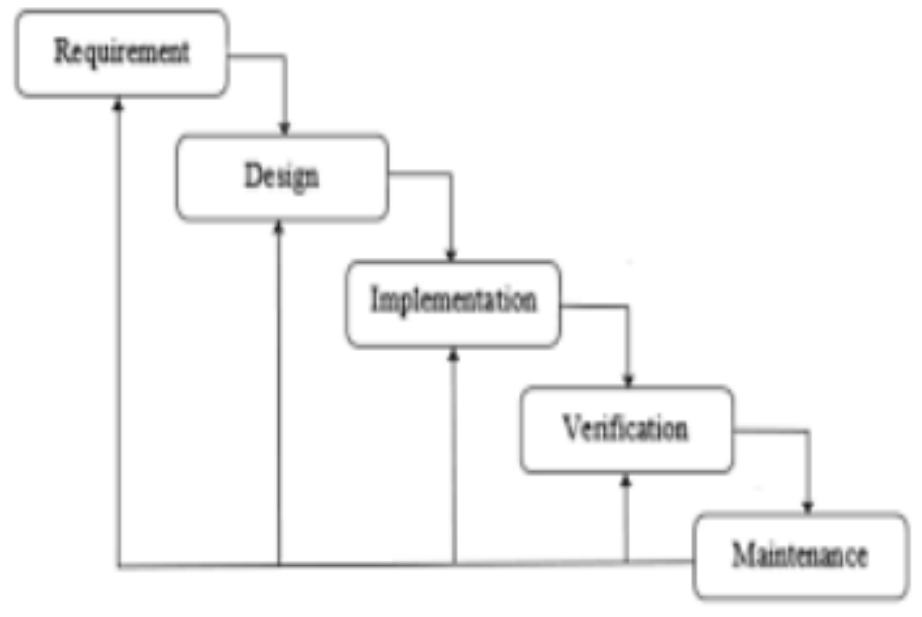

Gambar 1. Tahapan Waterfall

\section{HASIL DAN PEMBAHASAN}

\subsection{Business Model Canvas (BMC)}

Business Model Canvas (BMC) merupakan metode untuk memodelkan bisnis dan dapat juga digunakan untuk melakukan implementasi strategi pemasaran[6]. Pada gambar 2 terlihat Model BMC dalam penelitian ini 
Business Model Canvas -

\begin{tabular}{|c|c|c|c|c|}
\hline \multirow[t]{2}{*}{$\begin{array}{l}\text { Key Partners } \\
\text { - Supplier bahan kain } \\
\text { - Ekspedisi Pengiriman } \\
\text { Pengrajin batik } \\
\text { - Penyedia domain dan } \\
\text { hosting } \\
\text { - Pemilik ruko } \\
\text { - Toko mesin jahit }\end{array}$} & $\begin{array}{l}\text { Key Activities } \\
\text { - Mencari bahan kain } \\
\text { - Mentakukan motifif yang pasa disukai } \\
\text { - Membuat website e- } \\
\text { commerce } \\
\text {. Promosi via media online } \\
\text { - Melakukan penjualan } \\
\text { - Meduk } \\
\text { Melakukan pengiriman }\end{array}$ & \multirow{2}{*}{ 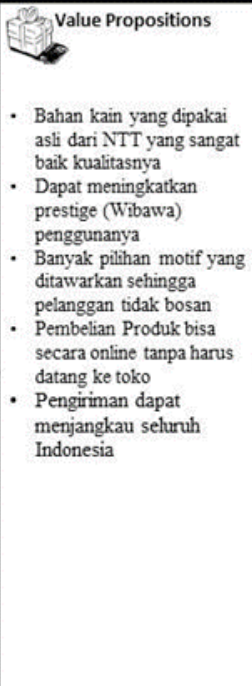 } & $\begin{array}{l}\text { Customer } \\
\text { Relationships } \\
\text { - Memberikan Diskon } \\
\text { kepada pelanggan } \\
\text { Memberikan layanan } \\
\text { support } 24 \text { jam melalui } \\
\text { toko online } \\
\text { Meminta testimoni dan } \\
\text { umpan balik kepada } \\
\text { pelanggan yang sudah } \\
\text { membeli produk ini. }\end{array}$ & \multirow[t]{2}{*}{$\begin{array}{l}\text { Customer Segments } \\
\begin{array}{l}\text { Pria dan Wanita (Usia } \\
\text { Dewasa) }\end{array}\end{array}$} \\
\hline & $\begin{array}{l}\text { Key Resources } \\
: \text { Pegawai } \\
: \text { Toko Fisik } \\
: \text { Laptop } \\
: \text { Handpone } \\
: \text { Hosting dan Domain } \\
: \text { Instagram } \\
\text { - Mesin jahit }\end{array}$ & & $\begin{array}{l}\text { Channels } \\
\text { - Website e-commerce } \\
\text { Instagram dan Whatsapp }\end{array}$ & \\
\hline $\begin{array}{l}\text { Cost Structure } \\
\text { - Biaya Sewa Ruko } \\
\text { - Biaya Gaji Pegawai } \\
\text { - Biaya Hosting dan Domai }\end{array}$ & -Biaya Listrik & - Penjualan & batik dan tenun & \\
\hline
\end{tabular}

Gambar 2. Business Model Canvas

BMC terdiri dari 9 blok yaitu Customer Segments, Value Propositions, Channels, Customer Relationship, Revenue Streams, Key Resources, Key Activities, Key Partnerships dan Cost Structure. Nilai lebih pada Irfana Batik Tenun ialah menggunakan bahan untuk membuat batik yang didatangkan langsung dari NTT dengan kualitas yang sangat baik, segmen pelanggan menyasar remaja dan dewasa, aktivitas utama yaitu melakukan penjualan produk dengan menyiapkan layanan help desk untuk berkomunikasi dengan pelanggan.

\subsection{Activity Diagram}

Activity Diagram digunakan untuk menampilkan proses bisnis yang terjadi pada irfana batik tenun sehingga proses bisnis yang terjadi mudah untuk dibaca dan dimengerti [7].

\section{a. Activity Diagram pada Proses Pemesanan Batik}

Pelanggan membuka website toko Irfana Batik Tenun kemudian melakukan login, lalu memlih kategori dan melihat katalog produk, selanjutnya pelanggan dapat menentukan ukuran dan jumlah batik. Setelah menentukan produk, pelanggan melakukan pembayaran dan pelanggan akan menerima email order, lalu admin melakukan verifikasi pesanan. Pada gambar 3 terdapat Activity diagram pemesanan. 


\section{b. Activity Diagram Pembayaran}

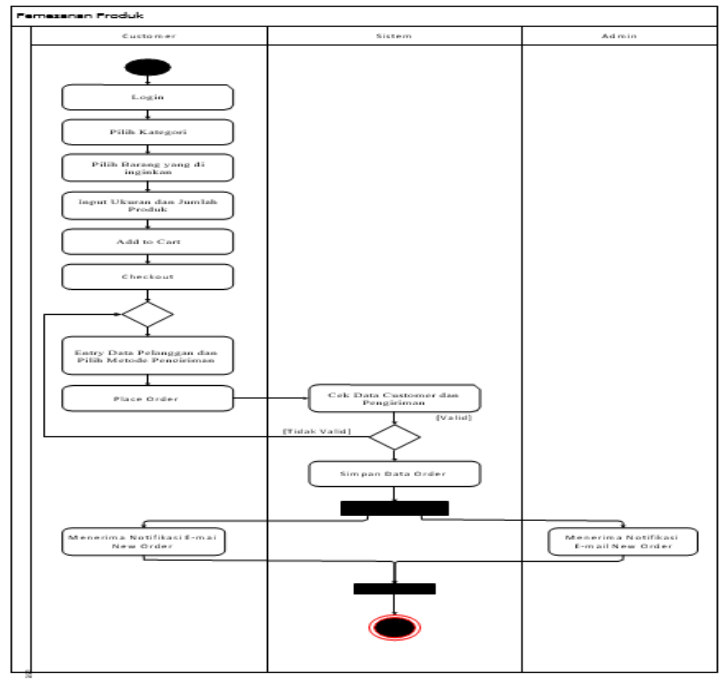

Gambar 3. Activity Diagram Pemesanan

Pelanggan melakukan pembayaran dan bukti pembayaran tersebut disimpan, pelanggan memilih menu konfirmasi pembayaran lalu memasukkan bukti pembayaran yang sudah dilakukan sebelumnya kemudian pilih kirim, sistem akan menyimpan data. Admin akan memeriksa bukti pembayaran tersebut kemudian mengubah status pembayaran, dan data akan disimpan.

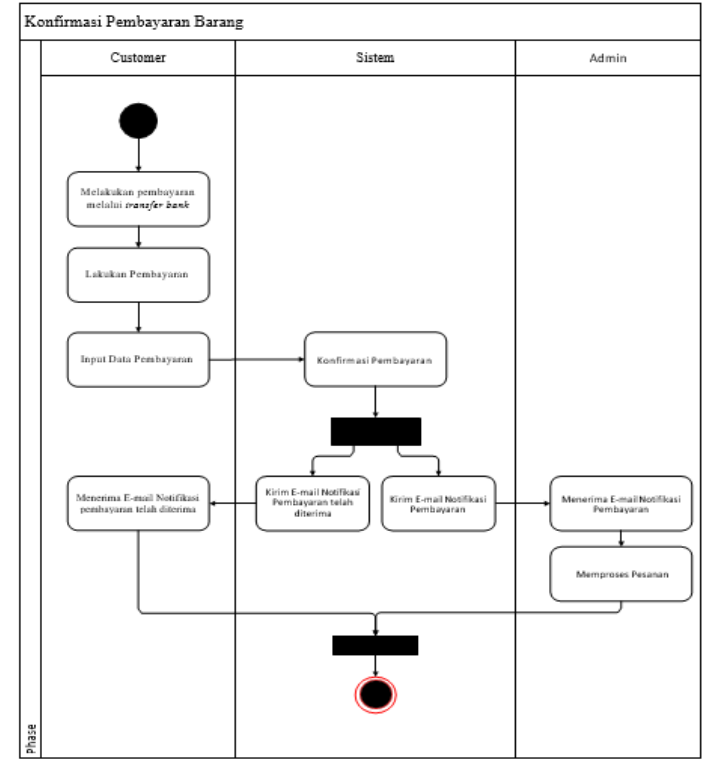

Gambar 4. Activity Diagram Pembayaran

\subsection{Use Case}

Use Case merupakan media yang digunakan untuk mendeskripsikan hubungan antara aktor dan sistem, apa saja yang dapat dilakukan oleh sistem dan gambaran menu dari aplikasi yang akan diimplementasikan [8].

\section{a. Use Case Transaksi}

Gambar 5 menampilkan Use case transaksi dalam penelitian. 

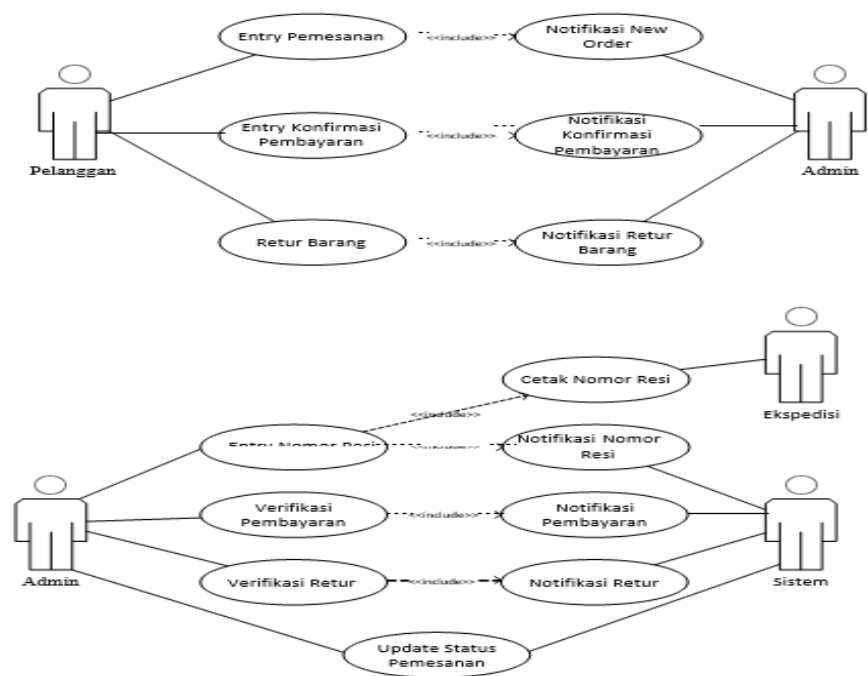

Gambar 5. Use Case Diagram Transaksi

\section{b. Use Case Laporan}

Gambar 6 menampilkan Use case laporan dalam penelitian ini.

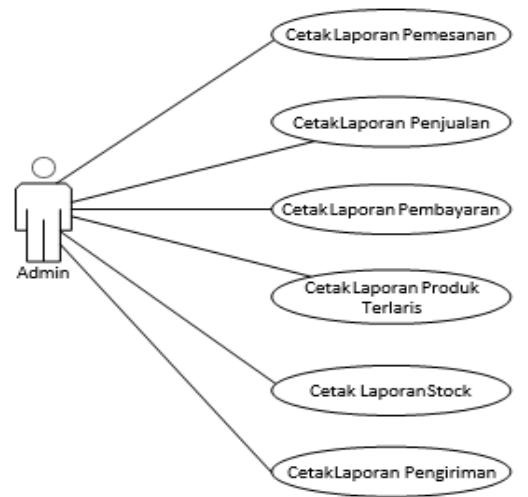

Gambar 6. Use Case Diagram Laporan

\subsection{Class Diagram}

Class diagram menggambarkan struktur sistem dari segi pendefinisian kelas-kelas yang akan dibuat untuk membangun sistem[9]. Gambar 7 merupakan class diagram dalam penelitian ini 

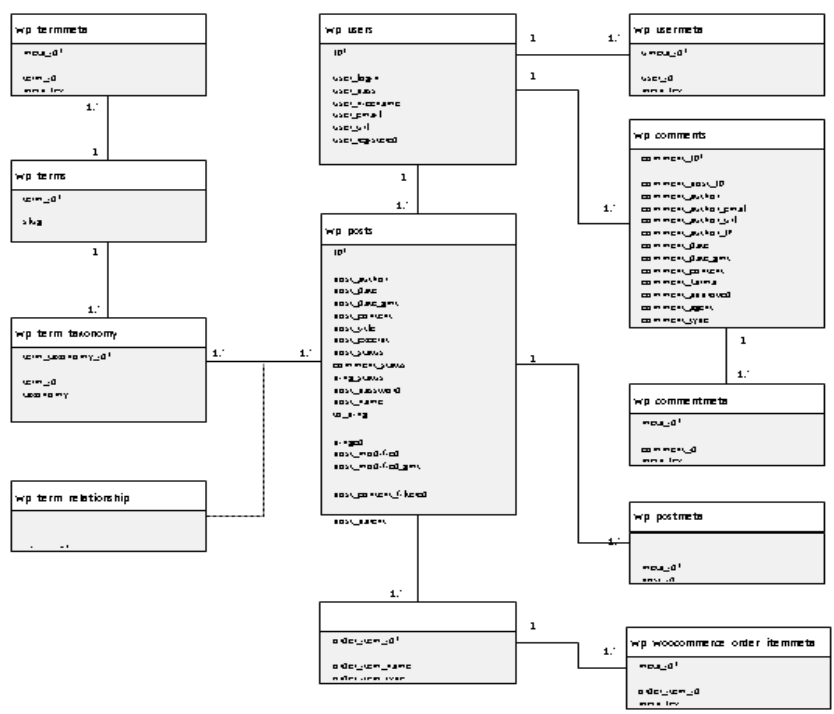

Gambar 7. Class Diagram

\subsection{Rancangan Layar}

Rancangan layar atau User Interface (UI) mengacu pada suatu sistem dan pengguna berinteraksi satu sama lain melalui perintah atau teknik untuk mengoperasikan sistem, memasukkan data, dan menggunakan konten[10].

a. Rancangan Layar Menu Utama

Dalam penelitian ini, rancangan layar menu utama dapat terlihat pada gambar 8 .

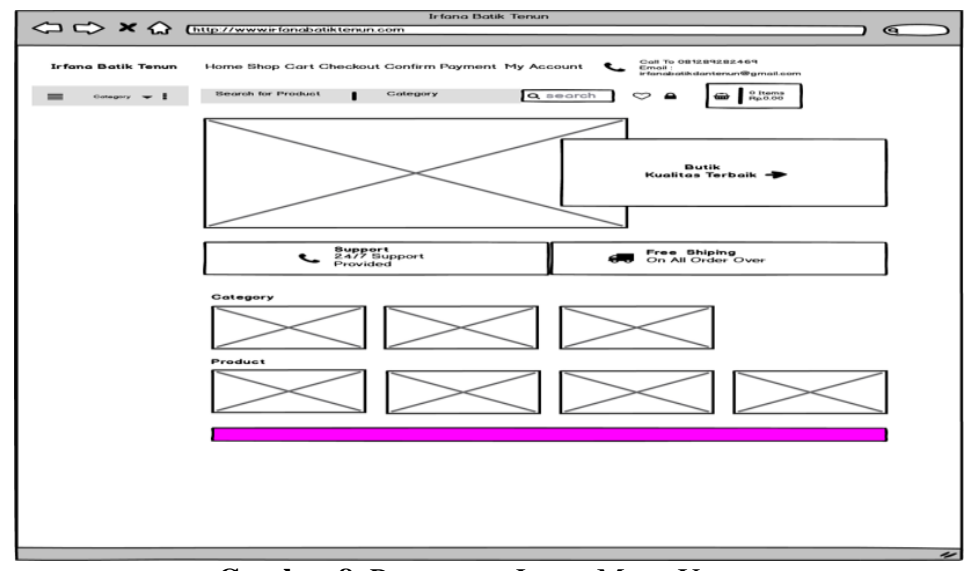

Gambar 8. Rancangan Layar Menu Utama

b. Rancangan Layar Pemesanan

Dalam penelitian ini, rancangan layar pemesanan dapat terlihat pada gambar 9. 


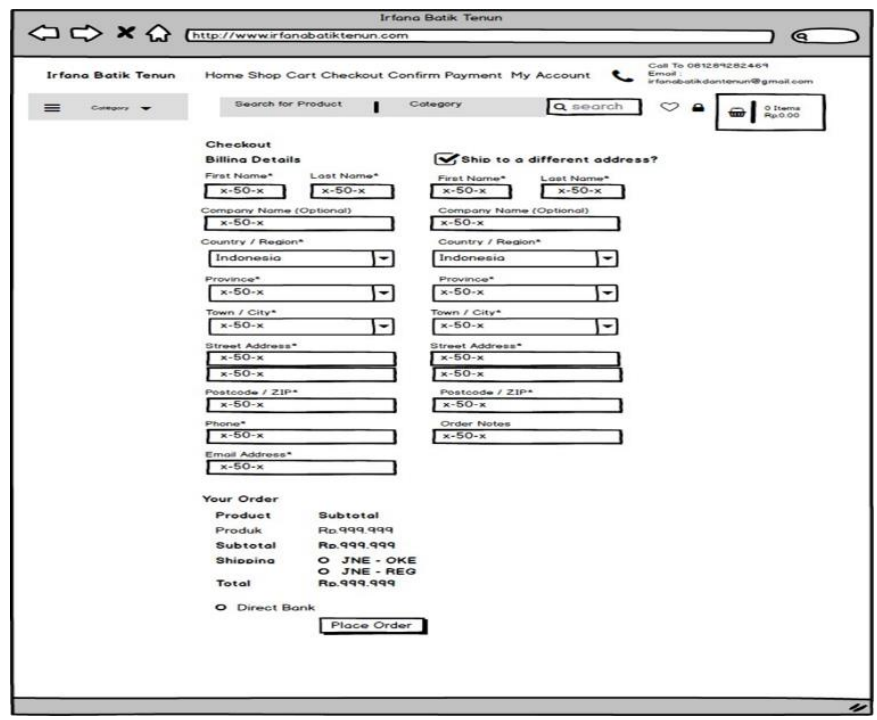

Gambar 9. Rancangan Layar Pemesanan

c. Rancangan Layar Pembayaran

Dalam penelitian ini, rancangan layar pembayaran dapat terlihat pada gambar 10.

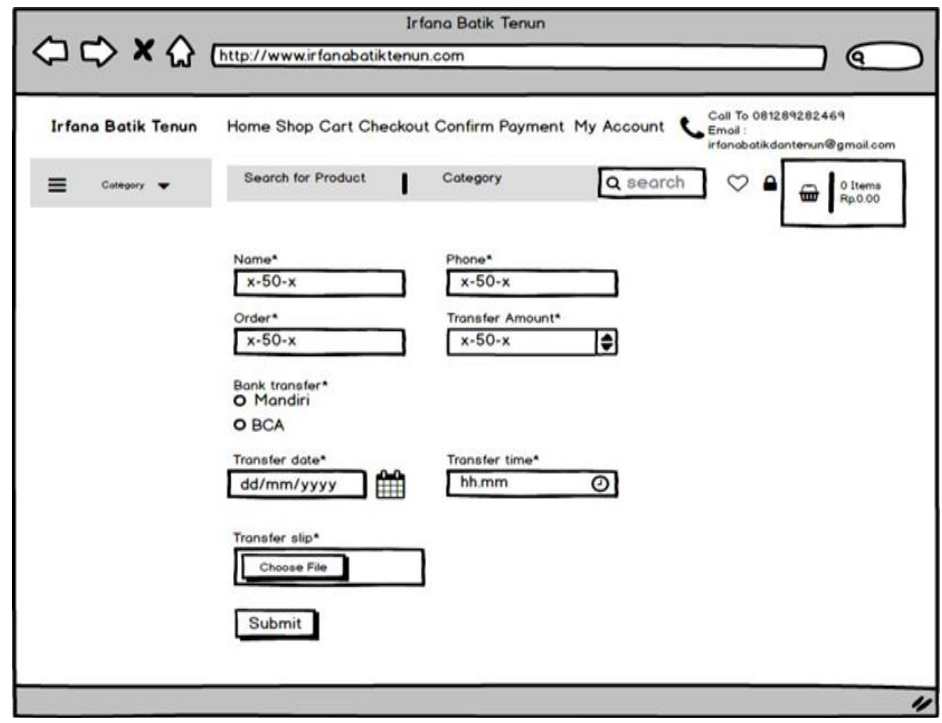

Gambar 10. Rancangan Layar Pembayaran

\section{KESIMPULAN}

Setelah melakukan serangkaian kegiatan penelitian pada irfana batik tenun didapatkan beberapa kesimpulan yaitu :

- Promosi \& pemasaran produk menjadi lebih luas

- Katalog produk selalu ter-update

- Kemudahan dalam melakukan transaksi

- Data penjualan terdokumentasi dengan baik

- Pemilik mudah dalam melakukan pengambilan keputusan

\section{DAFTAR PUSTAKA}

[1] Elisabet Yunaeti Anggraeni dan Rita Irviani, "Pengantar Sistem Informasi”, Andi: Yogyakarta, 2017.

[2] Jeperson Hutahaean, "Konsep Sistem Informasi”, Deepublish: Yogyakarta, 2016. 
INDONESIA JOURNAL INFORMATION SYSTEM (IDEALIS)

Volume 5, Nomor 1, Januari 2022

ISSN 2684-7280 (online)

Halaman 1-8

available online at http://jom.fti.budiluhur.ac.id/index.php/IDEALIS/index

[3] Rintho, Rante Rerung., "E-Commerce Menciptakan Daya Saing Melalui Teknologi Informasi”. Deepublish: Yogyakarta, 2017.

[4] Sugiyono, "Metode Penelitian Kuantitatif, Kualitatif, R \& D”, CV Alfabeta : Bandung, 2017.

[5] Muharto, dan Ambarita Arisandy, "Metode Penelitian Sistem Informasi", Deepublish : Yogyakarta, 2016.

[6] Aji, B., Wilopo, dan Nuralam, I.P. Implementasi Value Proposition Dalam Penerapan Strategi Pemasaran. Jurnal Administrasi Bisnis (JAB), 2017, Vol.53 No.1, pp. 21-30.

[7] Bagaskara, Riyan 2018., Apa yang dimaksud dengan Diagram aktivitas atau Activity Diagram ?. https://www.dictio.id/t/apayang-dimaksud-dengandiagram-aktivitas-atau-activity-diagram/15129. Diakses pada tanggal 10 Desember 2021

[8] Sri Mulyani, "Metode Analisis dan Perancangan Sistem", Edisi Kedua, Bandung, Abdi Sistematika, 2016.

[9] Sukamto, \& Shalahuddin, “Analisa dan Desain Sistem Informasi”, Andi Offset : Yogyakarta, 2018.

[10] Joo, Heonsik.. A Study on Understanding of UI and UX, and Understanding of Design According to User Interface Change. India: Research India Publication, 2017, pp. 1. 